\title{
Motivasi Partisipasi Politik Perempuan Pada Pemilu Legislatif 2019 di Kabupaten Ogan Komering Ulu
}

\author{
Herwin Sagita Bela $^{1)}$, Alip Susilowati Utama ${ }^{2)}$ \\ 1)2) Program Studi Ilmu Pemerintahan, Universitas Baturaja \\ Jl. Ki Ratu Penghulu Karang Sari No. 02301, Baturaja Sumatera Selatan \\ Email:herwinsb@gmail.com ${ }^{1)}$, alipsusilo93@gmail.com ${ }^{2}$
}

\begin{abstract}
Political participation is a measure of the success of the democratization process because in political participation there is citizen control of government. At present political participation which is still an interesting theme to be investigated is women's political participation. This is inseparable from the existence of the affirmative action movement which wants equal opportunities for women to participate in the political constellation. At present, the influence of political participation in the regions is an important note for central government policy. Therefore, it is important to know the prospects for women's political participation in the region. The results showed that the affirmative action policy actually has a side that can be beneficial but also detrimental to women and political parties. Many of the opportunities with this policy are not exploited because in fact many women do not have the desire to participate in political contestation. This is inseparable from the social support from women in the form of social, economic and cultural support. Most women will think long when it comes to family permits and the economic conditions of the family and culture that surrounds it so far. Therefore, the party also experienced difficulties in recruiting and cadre of party members because most were constrained by these factors although in terms of women's political orientation, they understood and had knowledge of the political system although they were not able to influence gender responsive policies at the district level.
\end{abstract}

Keywords : Prospects, Motivation, Women's Political Participation

\begin{abstract}
Abstrak
Partisipasi politik merupakan tolak ukur keberhasilan proses demokratisasi karena dalam partisipasi politik terdapat kontrol warga negara terhadap pemerintahan. Saat ini partisipasi politik yang masih menjadi tema yang menarik untuk diteliti adalah partisipasi politik perempuan. Hal ini tidak terlepas dari adanya gerakan affirmative action yang menginginkan adanya peluang yang sama bagi perempuan untuk ikut serta dalam konstelasi politik. Saat ini juga, pengaruh dari partisipasi politik di daerah menjadi catatan penting bagi kebijakan pemerintah pusat. Oleh sebab itu, penting untuk mengetahui bagaimana prospek partisipasi politik perempuan di daerah. Hasil penelitian menunjukkan bahwa kebijakan affirmative action sebenarnya memiliki sisi yang dapat menguntungkan namun juga merugikan bagi perempuan dan partai politik. Peluang dengan adanya kebijakan ini banyak tidak termanfaatkan karena pada faktanya banyak perempuan tidak memiliki keinginan untuk berpartai dan ikut dalam kontentasi politik. Hal ini tidak terlepas dari dukungan sosial dari perempuan berupa dukungan sosial, ekonomi dan budaya. Kebanyakan perempuan akan berpikir panjang jika menyangkut izin keluarga dan kondisi perekonomian keluarga dan budaya yang melingkupinya selama ini. Oleh sebab itu, partai juga mengalami kesulitan dalam perekrutan dan pengkaderan anggota partai karena sebagian besar terkendala dengan faktor tersebut meskipun dari sisi orientasi politik perempuan, mereka memahami dan memiliki pengetahuan tentang sistem politik meskipun belum mampu mempengaruhi kebijakan yang bersifat responsif gender di tingkat Kabupaten.
\end{abstract}

Kata kunci : Prospek, Motivasi, Partisipasi Politik Perempuan 


\section{Pendahuluan}

Partisipasi politik perempuan saat ini masih menjadi kajian yang sangat menarik.Hal ini berkaitan dengan gerakan affirmative action yang sudah diwacanakan sejak tahun 1995 di dunia melalui kongres APU (Asosiasi Uni Parlemen). Sebagaimana diketahui gerakan affirmative action merupakan suatu gerakan yang menuntut perempuan mempunyai peluang yang sama dengan laki-laki di ruang publik, seperti politik. Di Indonesia gerakan affirmative action mulai diwacanakan pada akhir tahun 1998 dan pada pemilu 1999 untuk pertama kalinya isu-isu mengenai hak-hak perempuan dalam politik mulai dikampanyekan meskipun hasil pemilu masih belum menunjukkan adanya kenaikan keterwakilan perempuan di parlemen yang hanya 9\% perempuan di DPR dan lebih rendah lagi di tingkat daerah (Wahid, 2014: 126).

Akan tetapi pada perkembangan partisipasi politik perempuan di Indonesia menunjukkan peningkatan meskipun tidak signifikan. Hal ini tidak terlepas dari dampak disahkannya Undang- Undang No. 31 Tahun 2002 tentang Partai Politik, Meskipun tidak spesifik mencantumkan presentase $30 \%$ keterwakilan perempuan tetapi penjelasan pasal 13 ayat 3 tercantum dengan jelas bahwa kesetaraan dan keadilan gender dicapai melalui peningkatan jumlah perempuan secara signifikan dalam kepengurusan partai politik di setiap tingkatan. Kemudian pada Undang- Undang No. 12 Tahun 2003 Tentang Pemilihan Umum Anggota Dewan Perwakilan Rakyat, Dewan Perwakilan Daerah, dan Dewan Perwakilan Rakyat Daerah pada pasal 65 ayat 1 secara spesifik menyebutkan setiap partai politik peserta pemilihan umum dapat mengajukan calon anggota DPR, DPRD Propinsi, DPRD Kabupaten/kota untuk setiap daerah pemilihan dengan memperhatikan keterwakilan perempuan sekurang-kurangnya $30 \%$.

Pada pemilu legislatif 2004, jumlah keterwakilan perempuan berada pada angka $11,09 \%$ sementara keterwakilan laki-laki mencapai $88,9 \%$. Sedangkan pada pemilu 2009, jumlah keterwakilan perempuan mengalami kenaikan yaitu $18,2 \%$. Akan tetapi pada pemilu 2014 mengalami penurunan menjadi 17, 3\%. Perolehan suara pada Pemilu Legislatif tahun 2014, mampu menghasilkan keterwakilan perempuan di legislatif sebanyak 97 kursi $(17,32 \%)$ di DPR, 35 kursi $(26,51 \%)$ di DPD, dan rata-rata $16,14 \%$ di DPRD serta $14 \%$ di DPRD kabupaten/kota ${ }^{1}$.

Fakta tersebut menunjukkan bahwa partisipasi politik perempuan di tengah konstelasi politik Indonesia yang cenderung patriarkhi masih menjadi satu tema penting untuk diteliti terlebih lagi partisipasi politik perempuan di tingkat Daerah karena daerah menjadi basis massa dimana partisipasi politik dengan esensi demokrasi dapat terpenuhi meskipun belum cukup baik. Oleh sebab itu, penelitian ini berfokus pada prospek dan motivasi perempuan pada pemilu legislatif 2019 di Kabupaten Ogan Komering Ulu.

\section{Pembahasan}

\section{A. Konsep Partisipasi politik dalam Demokrasi}

Menurut Joseph Schumpeter, demokrasi dalam pengertian sederhana adalah sebuah metode politik, sebuah mekanisme untuk memilih pemimpin politik. Warga negara diberikan kesempatan untuk memilih salah satu pemimpin politik yang bersaing, pada pmilihan berikutnya, masyarakat boleh mengganti pilihan mereka akan calon pemimpin politik.

Kemampuan dalam memilihdiantarapemimpinpemimpinpadamasapemilihaninilahyangdisebutdengande mokrasi. (Sorensen, 2014:14). Schumpeter juga menegaskan bahwa demokrasi pada intinya adalah metode penataan kelembagaan untuk sampai pada keputusan politik dimana invidu meraih kekuasaan untuk mengambil keputusan melalui perjuangan kompetitif untuk meraih suara. (Sorensen,2014:14).

Merujuk pada pengertian demokrasi oleh Schumpeter, pengertian demokrasi yang lebih komprehensif disampaikan oleh David Held. Menurut Held, dalam sistem demokrasi terdapat prinsip dasar otonomi. Dalam pengertian ini, setiap orang seharusnya bebas dan setara dalam menentukan kondisi kehidupannya. Yaitu mereka harus memperoleh hak yang sama karena adanya faktor kewajiban yang sama. Pada prinsip ini, Held menyebutkan bahwa otonomi demokrasi akan meramalkan partisipasi subtansial secara langsung pada lembaga komunitas politik. Pada konteks ini, otonomi demokrasi membutuhkan penyataan hakhak manusia diluar hak memilih untuk memberikan kesempatan yang sama untuk berpartisipasi dan untuk menemukan preferensi pribadi dan pengawasan akhir oleh arga negara terhadap agenda politik. Termasuk juga hak-hak sosial dan ekonomi yang digunakan untuk memastikan ketersedian sumber daya yang cukup untuk otonomi demokrasi. Karena tanpa hak sosial dan hak ekonomi yang kuat, hak-hak yang berhubungan dengan negara tidak akan diperoleh sepenuhnya. Sebaliknya, tanpa hak-hak negara akan menjadikan ketimpangan kekuasaan, kesejahteraan dan status secara sistematis akan mengacaukan implementasi kebebasan sosial dan ekonomi (Sorensen, 2014:15).

Berdasarkan pada pengertian di atas, dalam sistem demokrasi, partisipasi merupakan suatu keharusan.Karena dalam praktek partisipasi politik, esensi dari demokrasi berupa persamaan, kebebasan dan keadilan dapat terealisasikan. Dalam pandangan Almond (1999), partisipasi politik bukan hanya sebatas keikutsertaan atau peranan dalam konteks kegiatanpolitik, akan tetapi diawali dengan adanya artikulasi kepentingan dimana seorang individu mampu mengontrol sumber daya politik, seperti halnya seorang pemimpin partai politik. (Sahid, 2011:176).

Sementara Huntington dan Nelson memberikan batasan partisipasi politik pada beberapa hal.Pertama, partisipasi politik menyangkut kegiatan dan aksi bukan hanya sikap-sikap yang dimunculkan oleh individu.Kedua, subjek yang dimasukkan dalam partisipasi politik adalah setiap individu, bukan hanya 
orang profesional dalam bidang politik.Ketiga, kegiatan yang dilakukan dimaksudkan untuk mempengaruhi setiap pengambilan keputusan pemerintah.Keempat, setiap kegiatan yang dilakukan dalam upaya mempengaruhi kebijakan pemerintah tetap dimasukkan dalam kategori partisipasi politik, terlepas apakah kegiatan tersebut mempunyai efek atau tidak, berhasil atau tidak.Kelima, partisipasi politik mencakup partisipasi otonom dan partsipasi yang dimobilisasi.(Sahid,2014).

Bersandar pada batasan tersebut, secara tidak langsung dapat dikatakan bahwa yang dimaksud dengan partisipasi politik mengarah pada dua unsur penting, yaitu subjek dan kegiatan.Adapun subjek dalam partisipasi politik adalah setiap warga negara yang mempunyai kepentingan dan preferensi tentang siapa yang seharusnya mememerintah mereka dan mengetahui tentang kebijakan publik yang dikeluarkan oleh mereka.Subjek juga ikut serta mempengaruhi setiap keputusan mengenai kebijakan publik dan secara tidak langsung respon mereka terhadap preferensi konsitutennya menjadi dasar pengembangan karir pejabat publik sehingga dalam pengertian ini, partisipasi politik terkait dengan rasionalitas dan responsiveness (Mujani, 2007:254).Karakter subjek yang demikian menunjukkan bahwa demokrasi melalui partisipasi politik menjadi kontrol pemerintah olehmasyarakat.

Selanjutnya, unsur terpenting dalam partisipasi politik adalah aksi atau kegiatan.Dalam hal ini, Kaase dan Marsh sebagaimana dikutip oleh Mujani (2007) menyebutkan bahwa aktivitas yang dilakukan oleh subjek terbagi menjadi dua, yaitu kovensional dan tidak konvesional. Bentuk konvensional melibatkan seluruh aktivitas oleh subjek untuk mempengaruhi outcomes dari proses politik dengan kegiatan yang dilaksanakan sesuai dengan prosedur atau aturan yang berlaku. Kegiatan ini berupa memberikan suara pada pemilu, menjadi kandidat untuk menduduki jabatan politik dan berkampanye. Sementara bentuk tidak konvensional melibatkan aktivitas yang dilakukan untuk mempengaruhi outcomes proses politik melalui aksi seperti demonstrasi, mogok kerja atau juga perusakan fasilitas umum (Mujani,2007:258).

\section{B. Teori Hirarki Kebutuhan Maslow}

Berkaitan dengan partisipasi politik perempuan, maka dalam penelitian perlu untuk mengetahui apa motivasi terbesar perempuan sehingga mampu menjadi calon legislatif pada pemilu legislatif 2019. Pada teori Hirarki Kebutuhan Maslow disebutkan bahwa terdapat empat kebutuhan dasar manusia dan satu kebutuhan meta. Empat kebutuhan tersebut adalah, pertama kebutuhan fisiologi.Kebutuhan ini menyangkut tentang sokongan kebutuhan fisik, seperti makan, minum, dan istirahat.Kedua, kebutuhan keamanan. Setelah kebutuhan fisiologi terpenuhi akan memunculkan kebutuhan lainnya berupa keamanan, stabilitas, proteksi, struktur hukum, keteraturan, batas dan kebebasan dari rasa takut dan cemas. Pada intinya, kebutuhan fisiologis dan keamanan adalah kebutuhan mempertahankan
kehidupan.Ketiga, kebutuhan dimiliki dan cinta. Pada kebutuhan ini, Maslow mendefinisikan cinta sebagai suatu hubungan yang sehat antar manusia yang melibatkan perasaan saling menghargai,menghormati dan mempercayai. Pada konteks ini, perasaan ingin dimiliki dan mencintai kelompok sosialnya menjadi tujuan yang dominan. Karena tanpa penerimaan dari rasa ingin dimiliki maka yang akan berdampakpadarasa kekosongan dan kemarahan yang mengarahkan pada hilangnya rasa kecintaan terhadap kelompok sosial tersebut. Keempat, kebutuhan harga diri.Dalam kebutuhan ini ada dua jenis harga diri. Yang pertama menghargai diri sendiri dan penghargaan dari orang lain. Adapun kepuasan dari kebutuhan ini memunculkan rasa percaya diri, diri berharga, diri mampu, dan perasaan berguna dan penting. Selanjutnya kebutuhan metayaitu aktualisasi diri. Sesudah seluruh kebutuhan dsar terpenuhi, muncullah kebutuhan meta atau kebutuhan aktualisasi diri, kebutuhan menjadi sesuatu yang orang itu mampu mewujudkan menggunakan seluruh kemampuan, bakat dan potensinya. Kebutuhan meta adalah kebutuhan karena ingin berkembang, ingin berubah dan ingin mengalami transformasi menjadi lebih bermakna (Alwisol, 2009:204- 206).

\section{Metode Penelitian}

Metode riset yang dipilih dalam penelitian ini adalah kualitatif, dimana pada metode penelitian ini dimaksudkan untuk mencari pemaknaan atau kedalaman atas sebuah permasalahan. Metode kualitatif merupakan suatu cara untuk mengetahui pemahaman mendalam sebuah makna oleh individu atau kelompok terhadap suatu masalah atau topik dengan proses yang diawali dari munculnya suatu pertanyaan yang kemudian dianalisis secara induktif menuju pada sesuatu yang lebih umum dan kemudian akan diciptakan interprestasi makna yang berasal dari hasil pertanyaan atau observasi dilapangan. Pada dasarnya penelitian kualitatif tidak dimulai dari sesuatu yang kosong, tetapi dilakukan berdasarkan persepsi seseorang terhadap adanya masalah (Moleong, 2012).Sedangkan masalah dalam penelitian kualitatif bertumpu pada sesuatu fokus.Fokus pada dasarnya adalah masalah pokok yang bersumber dari pengalaman peneliti atau melalui pengetahuan yang diperolehnya melalui kepustakaan ilmiah atau pun kepustakaan lainnya.Berdasarkan rumusan masalah dan tujuan penelitian maka fokus penelitian adalah prospek dan motivasi partisipasi politik perempuan dalam pemilu legislatif 2019

Penentuan informan dalam penelitian ini menggunakan teknik purposive sampling.Informan dalam penelitian ini adalah perempuan calon legislatif daerah dari partai-partai yang mengikuti pemilu 2019.Sedangakan data pada penelitian ini terbagi menjadi dua, yaitu data primer berupa hasil wawancara dengan perempuan calon legislatif dan data sekunder berupa dokumen-dokumen pendukung yang dapat memberikan kontribusi pada analisis data primer.

Adapun teknik pengumpulan data dilakukan melalui observasi, wawancara dan dokumentasi.Masing-masing 
teknik mempunyai panduan tersediri guna memperoleh data yang merujuk pada pemenuhan fakta permasalahan dan solusi yang diingginkan pada penelitian.

Proses analisis data dilakukan secara terus menerus dimulai dari pengumpulan informasi dari wawanncara, observasi dan dokumentasi. Dilanjutkan dengan reduksi data yang befungsi memilih dan memusatkan perhatian pada masalah utama penelitian. Setelah proses ini kemudian dilanjutkan dengan penyajian data berupa deskripsi analisis data yang sudah disederhanakan dan dipilah bedasarkan fokus penelitian.

\section{Hasil}

1. Gambaran Partisipasi Politik Perempuan dan Prospeknya di Kabupaten Ogan Komering Ulu

Pada beberapa kajian tentang demokrasi disebutkan bahwa demokrasi bukan semata manipulasi kaum borjuis namun demokrasi lebih mengarah pada suatu nilai budaya atau kebudayaan yang mempunyai makna, simbol, sekumpulan nilai, kepercayaan, sikap, dan tata cara serta gaya hidup yang telah ada sejak demokrasi diberlakukan. Hal ini tidak terlepas dari proses panjang perjalanan demokrasi .nilai-nilai demokrasi yang telah dipahami bersama oleh masyarakat inilah yang kemudian menjadikan demokrasi sebagai paradigma baru, tidak hanya berkaitan dengan politik namun juga berkaitan dengan sistem ekonomi dan sosial (Sorensen, 2003: 17)

Oleh sebab itu, budaya demokrasi adalah suatu perilaku, praktek dan norma-norma yang mejadi pedoman tentang kemampuan rakyat untuk memerintah dirinya sendiri, yang kemudan membentuk suatu otoritas yang dipilih secara bebas melalui suatu mekanisme yang telah disepakati bersama.Otoritas inilah yang kemudian bertanggung jawab atas hak masyarakat secara umum dan menjamin terpenuhinya kepentingan-kepentingan mereka sendiri, dalam konteks inilah partisipasi politik tercipta.

Pada negara demokrasi, partisipasi politik merupakan satu hal yang penting. Perjalanan demokratisasi suatu bangsa akan sangat dipengaruhi oleh jumlah partisipasi politik masyarakatnya. Angka partisipasi politik masyarakat dapat menjadi tolak ukur perjalanan demokratisasi suatu bangsa. Oleh sebab itu, tanpa partisipasi mustahil demokrasi akan terwujud. Di Indonesia, angka partisipasi politik ditunjukkan dengan tingginya angka partisipasi pemilih pada penyelenggaraan pemilihan umum secara berkala. Dalam perkembangan sejarah demokrasi di Indonesia, demokrasi telah mengalami pasang surut. Indonesia pernah menjadi negara dengan demokrasi terpimpin, demokrasi semi otoriter dan demokrasi pancasila yang mengedepankan pelaksanaan nilai-nilai pancasila dalam proses demokratisasi.

Pada proses peralihan sistem demokrasi digunakan di Indonesia, masing-masing menunjukkan angka partisipasi politik yang berbeda. Pada pemilu pertama tahun 1955 partisipasi politik mencapai 91,4\% dengan angka golput hanya $8,6 \%$. Sementara pada pemilu era orde baru tahun 1971 partisipasi politik mencapai 96,6\% dan mengalami penurunan angka golput yang hanya mencapai 3,4\%. Pada pemilu 1977 dan pemilu 1982, partisipasi politik mencapai angka 96,5\% dengan angka golput hanya $3,5 \%$. Perolehan ini tidakberbeda jauh dengan perolehan angka partisipasi politik pada pemilu 1982 yang mencapai angka 96,4\% dengan angka golput $3,6 \%$.

Angka partisipasi politik di Indonesia masih menunjukkan tingginya angka partisipasi politik pada pemilu-pemilu setelahnya. Seperti pemilu tahun 1992, partisipasi politik masih berada diangka $95,1 \%$ dengan angka golput mencapai $4,9 \%$. Sementara pada pemilu 1997, partisipasi politik pemilih mencapai 93,6\% namun jumlah golput meningkat menjadi $6,4 \%$. Sedangkan pada pemilu pertama pasca reformasi yaitu pemilu 1999, tingkat partisipasi politik masih tinggi dengan angka yang mencapai 92,6\% dengan angka golput mencapai 7,3\%. Akan tetapi pada pemilu 2004, partisipasi politik pemilih mengalami penurunan yang hanya mencapai $84,1 \%$ dengan angka golput meningkat hingga $15,9 \%$.

Hal ini diperparah dengan angka perolehan partisipasi politik pada pilpres 2004 putaran pertama yang hanya mencapai angka 78,2\% dengan angka golput mencapai $21,8 \%$. Sementara pada pilpres putaran kedua, angka partisipasi menurun menjadi $76,6 \%$ dengan golput yang meningkat menjadi $23,4 \%$.

Angka partisipasi politik pemilih di Indonesia terus mengalami penurunan hingga hanya mencapai $70,9 \%$ dengan jumlah golput mencapai $29,1 \%$ pada pemilu 2009. Sedangkan pilpres tahun 2009 angka partisipasi hanya mencapai $71,7 \%$ dengan angka golput mencapai 28,3\%. Pada pemilu 2014, angka partisipasi politik mencapai angka $75,2 \%$ dengan angka golput $24,8 \%$ (disadur dari laman berita merdeka dengan judul ini tingkat partisipasi pemilih dari Pemilu 1955 - 2014 yang ditulis oleh Yulistyo Pratomo dan Randy Ferdi Firdaus pada hari Sabtu 12 April 2014).

Pada konteks partisipasi politik, kajian tentang partisipasi politik perempuan juga menjadi kajian yang menarik mengingat peranan perempuan itu sendiri dalam politik.Sejarah menuliskan bahwa perempuan berada dalam situasi yang disebut dengan second sex.Situasi ini yang kemudian membuat perempuan menjadi termarginalkan dalam struktur lingkungan baik itu sosial maupun politik. Pada titik ini, perempuan menjadi tidak mempunyai kekuatan untuk menginisiasi kepentingan mereka dalam lingkungan sosial dan politik, padahal jika dilihat dari keharusan partisipasi politik dalam negara demokrasi, setiap elemen masyarakat mempunyai kewajiban yang sama untuk berpartisipasi tanpa memandang umur, pekerjaan dan jenis kelamin.

Pada beberapa kajian tentang partisipasi politik perempuan selalu dinyatakan bahwa budaya suatu bangsa dapat berpengaruh total pada angka partisipasi perempuan. Di Indonesia khususnya, dengan mayoritas masyarakatnya menganut sistem patriarki tentu membuat ruang gerak perempuan menjadi sempit karena pandangan budaya yang menganggap bahwa perempuan hendaknya hanya boleh berada pada posisi setelah lakilaki.Kondisi ini kemudian menjadi pemicu gerakan- 
gerakan yang mendukung perluasan ruang gerak perempuan agar tidak terbatasi oleh stigma budaya.

Gerakan-gerakan untuk membuka peluang bagi munculnya partisipasi perempuan yang lebih aktif lagi diwujudkan melalui kebijakan affirmative action.Kebijakan ini diawali dengan kongres Asosiasi Uni Parlemen yang diadakan pada tahun 1995.Sejak saat itu, gerakan perempuan menjadi gencar untuk diwujudkan.Di Indonesia sendiri isu tentang partisipasi perempuan dalam politik mulai digagas sejak tahun 1998 dan 1999. Adapun perwujudan dari kebijakanaffirmative action di Indonesia mulai diberlakukan melalui beberapa Undang-undang, yaitu Undang-undang Nomor 31 Tahun 2002 Tentang Partai Politik. Pada penjelasan paal 13 ayat 3 bahwa dalam setiap kepengurusan partai politik disetiap tingkatan harus terdapat jumlah peningkatan partisipasi perempuan untuk menciptakan kesetaraan gender.Pada pasal ini dinyatakan tidak secara explisit menyebutkan tentang kuota $30 \%$ keterwakilan perempuan namun harus ada peningkatan dalam kepengurusan partai yang artinya harus berlaku secara berkelanjutan bagi partai tersebut. Selain Undangundang tersebut, penyebutan kuota $30 \%$ keterwakilan perempuan dalam parlemen dijelaskan dalam Undangundang Nomor 12 Tahun 2003 Tentang Pemilihan Umum Anggota DPR, DPD dan DPRD. Pada pasal 65 ayat 1 disebutkan bahwa setiap partai politik peserta pemilu dapat mengajukan calon DPR, DPD dan DPRD dengan memperhatikan keterwakilan perempuan sekurang-kurangnya $30 \%$.Melalui aturan ini, agenda besar dalam menyusun kebijakan yang responsif gender semakin mudah untuk diwujudkan.

Sepanjang kurun waktu hampir 20 tahun sejak isu tentang partisipasi perempuan, saat ini peningkatan angka partisipasi perempuan masih belum menunjukkan peningkatan yang signifikan, meskipun pada catatan pemilu 2004, jumlah keterwakilan perempuan hanya mencapai angka 11,09\% sedangkan partisipasi laki-laki mencapai 88,9\%. Pemilu 2009 angka partisipasi politik perempuan naik menjadi $18,2 \%$ dan menurun pada pemilu 2014 menjadi 17,3\%. Pada pemilu 2014 perolehan suara untuk calon legislatif perempuan hanya $17,32 \%$ di DPR, $26,51 \%$ di DPD dan $16,14 \%$ di DPRD provinsi dan hanya $14 \%$ di DPRD Kabupaten/Kota. Angka ini masih terlalu kecil dibandingkan dengan Negara-negara demokratis di Skandinavia.

Dari data di atas, dapat dilihat bahwa angka partisipasi politik perempuan pada masyarakat di tingkat nasional dan tingkat Kabupaten memiliki presentase yang tidak jauh berbeda. Dalam pandangan Hans Antlov (Halim:2014) terdapat satu istilah dalam peningkatan partisipasi politik, terutama di Daerah. Istilah tersebut adalah go local politics yang merupakan kecenderungan yang bisa dibangun melalui dua jalur yaitu perluasan pemahaman dan wawasan politik lokal serta eksperimen tentang partisipasi masyarakat. Melalui istilah ini, dikatakan bahwa partisipasi di Daerah menentukan partisipasi di tingkat Nasional dan atau sebaliknya.Dan dalam kurun waktu 20 tahun sejak isu tentang perempuan mulai dimunculkan, partisipasi politik perempuan masih berada diposisi yang belum menguntungkan terutama di Daerah.

Salah satu Kabupaten yang menjadi fokus kajian pada penelitian ini adalah Kabupaten Ogan Komering Ulu.Salah satu Kabupaten tertua di Sumatera Selatan. Pada tahun 2004, Kabupaten Ogan Komering Ulu terpecah menjadi tiga Kabupaten, yaitu Kabupaten Ogan Komering Ulu, Kabupaten Ogan Komering Ulu Timur dan Kabupaten Ogan Komering Ulu Selatan. Sebagaimana yang diketahui bahwa pemekaran Kabupaten dilakukan agar masalah jangkauan pelayanan dan pembinaan masyarakat dapat dilakukan dengan lebih baik serta dapat memberikan keleluasaan bagi Kabupaten tersebut berkembang secara ekonomi, budaya, sosial dan politik.Dalam hal ini, dinamika politik juga menjadi point penting dalam pemekaran wilayah Kabupaten.

Dengan luasan $2.773 \mathrm{~km}^{2}$ wilayah Kabupaten Ogan Komering Ulu jauh lebih kecil dibandingkan dengan luasan Kabupaten Ogan Komering Ulu Timur dan Kabupaten Ogan Komering Ulu Selatan.Dengan sebaran wilayah yang tidak terlalu jauh dan mayoritas penduduk berada di lingkungan perkotaan, maka asumsinya tingkat partisipasi masyarakatnya lebih tinggi dibanding masyarakat di wilayah luar Kabupaten atau wilayah pedesaan.Bukan hanya partisipasi politik pemilih namun juga partisipasi keikutsertaan dalam kontetasi politik. Pada kenyataannya, partisipasi politik pemilih perempuan mencapai $80 \%$ namun partisipasi keikutsertaan perempuan dalam kontentasi politik hanya 12\% dari 35 kursi di DPRD pada tahun 2014, sementara perolehan kursi perempuan pada pemilu 2019 turun menjadi 6\% dari total 35 kursi.Kemuduran ini menurut Ketua partai sekaligus legislatif terpilih dari Partai Persatuan Pembangunan Ibu Umi Hartati adalah akibat dari minimnya pengetahuan politik dan masih tingginya budaya patriarkhi serta tingkat kepercayaan masyarakat yang rendah terhadap calon legislatif perempuan.

Pada konteks ini, partisipasi politik perempuan dilihat dari keikutsertaan perempuan dalam kiprah politik secara nyata melalui pencalonan perempuan sebagai calon legislatif. Sementara partisipasi pemberian suara pada saat pemilu dianggap sudah memenuhi prasyarat demokrasi.

Pada banyak kasus calon legislatif perempuan di Kabupaten Ogan Komering Ulu, perempuan hanya menjadi objek pemenuhan bagi partai agar dapat ikut serta dalam pemilu. Persyaratan tersebut pada kenyataannya menjadikan partai terbebani karena harus berjuang lebih keras untuk merekrut calon kader partai dari perempuan. Hal ini menjadi permasalahan karena tidak sesuai dengan semangat affirmative action yang berusaha menekan lingkungan sosial perempuan untuk memberikan ruang yang sama bagi perempuan dalam politik namun pada kenyataannya perempuan secara pribadi belum mempunyai keinginan untuk ikut serta dalam kontetasi politik.

Permasalahan ini juga berkaitan dengan gerak partai dalam memberikan pendidikan politik kepada perempuan. Sebagaimana dijelaskan oleh Indrawati 
Syahrial, salah seorang calon legislatif sekaligus Ketua DPC Partai Demokrat di Kabupaten Ogan Komering Ulu, partai politik telah melakukan proses pendidikan politik kepada Masyarakat sesuai dengan amanat Undang-undang. Namun pada proses ini, ketertarikan perempuan yang hidup dalam budaya patriarhki dan stigma mereka terhadap politik menjadi lemah. Siklus ini berlaku pada setiap generasi. Bahkan saat ini muncul apatisme perempuan milineal terhadap politik.

Sementara Umi Hartati Ketua DPC Partai PPP menjelaskan bahwa ketidaktertarikan perempuan dalam politik disebabkan oleh rendahnya dukungan sosial dari keluarga dan kerabat perempuan itu sendiri. Kebanyakan calon anggota legislatif yang bertahan dan mampu menduduki kursi di DPRD adalah pemain lama yang memang sudah lama berkecimpung dalam dunia partai politik. Sementara tokoh-tokoh baru perempuan sangat minim di Kabupaten Ogan Komering Ulu. Dukungan sosial dalam hal ini adalah dukungan keluarga menjadi point penting bagi perempuan dalam politik. Izin suami, izin orangtua, keluarga besar sangat besar pengaruhnya bagi perempuan karena sebagaimana diketahui bahwa kegiatan politik yang akan dijalankan banyak menyita waktu perempuan dan ini menjadi pokok permasalahan dalam keluarga. Oleh sebab itu, penting untuk membangun image tentang politik yang baik agar dukungan sosial mudah didapatkan.

Dari ulasan tersebut, kedua tokoh perempuan di Kabupaten Ogan Komering Ulu mempunyai pernyataan yang sama tentang prospek partisipasi perempuan di Kabupaten Ogan Komering Ulu. Mereka berpandangan bahwa dari perolehan suara yang didapat perempuan di Kabupaten saat ini tidak dapat menjadi ukuran bagi terpenuhinya angka yang lebih besar di DPRD pada 5 tahun kedepan. Hal ini dikarenakan sikap dan tingkat kepercayaan perempuan sebagai pemilih maupun sebagai seorang calon legislatif dapat berubah dan mudah dipengaruhi. Oleh sebab itu, pekerjaan rumah terberat ada di partai politik sebagai alat pendidikan politik yang paling tepat untuk memberikan pendidikan dan membangun image partai politik yang baik, sehingga dapat menaikkan angka kepercayaan masyarakat terhadap lembaga-lembaga politik. Dan hal ini akan berdampak pada munculnya perempuan-perempuan milenial yang sadar politik dan mempunyai motivasi untuk sama-sama membangun Daerah.

\section{Orientasi Politik Calon Legislatif Perempuan di} Kabupaten Ogan Komering Ulu

Orientasi politik dalam pandangan Almond dan Verba (1984) dianggap sebagai bentuk pengertian budaya yang dilihat melalui perasaan, pemikiran dan sikap manusia dengan objek yang berfokus pada nilainilai, simbol-simbol dalam sistem politik. Orientasi juga dianggap sebagai bentuk pernyataan pemikiran dan sikap manusia terhadap proses politik. Objek yang berfokus pada sistem politik terdapat tiga komponen yang saling menunjang.Ke tiga komponen tersebut adalah komponen kognitif, afektif dan evaluatif.

\section{a. Orentasi Kognitif}

Komponen kognitif melihat pengetahuan dan kepercayaan pada politik, tokoh-tokoh pemerintahan, kebijaksanaan yang diambil dan simbol-simbol yang dimiliki dalam sistem politiknya, peranan dan kewajiban dalam sistem politik serta input dan outputnya (Almond, Verba: 1984).

Hasil observasi pada saat penelitian lapangan menunjukkan bahwa tingkat pengetahuan politik beberapa calon legislatif perempuan yang dipilih sebagai informan masuk dalam katagori baik. Calon legislatif perempuan yang diajukan oleh beberapa Partai seperti Partai Demokrat, Partai Persatuan Pembangunan, dan Partai Nasdem adalah calon yang memang melalui proses rekrutmen dan pengkaderan di partai tersebut. Dalam proses pengkanderan, simbol-simbol dalam partai yang menjadi ideologi partai tersebut akan disosialisasikan kepada para kader sehingga kemampuan bagi sebagaian kader partai akan dengan baik mengenali simbol-simbol politik, peranannya dalam politik dan kewajiban mereka dalam politik serta mampu memahami input dan output dari suatu sistem politik.

Hal ini tidak terlepas dari dukungan kebijakan affirmative action.Saat ini perempuan telah memiliki ruang untuk menyuarakan aspirasinya di ranah politik tanpa takut adanya dominasi dari laki-laki. Meskipun dalam pandangan beberapa pengamat politik pemberlakuan kuota $30 \%$ bagi perempuan tetap dipandang sebagai bentuk diskriminasi perempuan, setidaknya kuota $30 \%$ merupakan satu pijakan bagi perempuan untuk lebih berani mengambil sikap untuk aktif di ruang publik.

Optimisme calon legislatif perempuan juga dipengaruhi oleh tingkat pendidikan.Menurut Umi Hartati (legislatif terpilih Kabupaten Ogan Komering Ulu tahun 2019) tingkat penerimaan pengetahuan politik banyak terserap oleh perempuan-perempuan dengan tingkat pendidikan yang tinggi.Sementara dengan perempuan lainnya cukup sulit untuk memberikan pemahaman politik karena stigma yang terbentuk di masyarakat yang mengatakan bahwa dunia politik bukan untuk perempuan dan terkesan memiliki konotasi buruk.Namun, potensi ketertarikan perempuan terhadap politik juga ditunjukkan oleh perempuan bukan dari kalangan berpendidikan.Pandangan ini menunjukkan bahwa tidak ada korelasi yang tepat antara minat berpolitik dengan tingkat pendidikan. Meskipun demikian, pendidikan akan lebih menunjang minat berpolitik karena berkaitan dengan pengetahuan politik seseorang. Dengan pengetahuan politik yang baik akan berpengaruh pada perilaku politik kedepannya.

Orientasi kognitif juga dapat dilihat dari seberapa besar tingkat kepercayaan calon legislatif perempuan terhadap lembaga-lembaga pemerintahan dan politik seperti partai politik.Pada konteks ini, kepercayaan pemilihan partai politik menjadi hal yang paling penting sebagai alat kepentingan bagi masing-masing calon legislatif.Kepercayaan politik dapat juga diartikan sebagai bentuk dukungan dari masyarakat terhadap sistem. 
Kepercayaan politik dapat dilihat dari dua hal mendasar.Pertama, kepercayaan terhadap individu tertentu yang berada pada suatu tingkatan kekuasaan.Kedua, kepercayaan terhadap institusi itu sendiri sebagaimana yang sudah disebutkan sebelumnya, seperti partai politik.Kepercayaan terhadap lembaga atau institusi lebih stabil dibandingkan dengan kepercayaan terhadap individu atau politisi.

Tingkat kepercayaan politik calon legislatif perempuan lebih tinggi pada kepercayaan individu atau politisi dibandingkan dengan kepercayaan terhadap institusi. Beberapa perempuan memilih partai yang akan dijadikan sebagai kendaraan politik berdasarkan pada konteks ketokohan atau figur partai tersebut. Sebagaimana yang diungkapkan oleh Indrawati Syarial salah seorang calon legislatif terpilih dari partai Demokrat menjelaskan bahwa pilihannya masuk ke Partai Demokrat karena semata ketokohan dari sosok Susilo Bambang Yudhoyono. Meskipun selain itu persamaan akan ideologi partai pun menjadi alasan untuk memilih partai yang dimaksud. Sementara pernyataan Umi Hartati dari Partai Persatuan Pembangunan mengatakan bahwa pilihan terhadap Partai Persatuan Pembangunan karena sudah turun menurun dari keluarga yang menjadi kader partai tersebut.Istilah sudah mendarah daging di partai ini juga disebutkan oleh Umi Hartati sebagai bentuk konotasi dari kecintaannya terhadap Partai Persatuan Pembangunan.

Pada tingkatan kepercayaan kepada Partai Politik dapat dihubungkan dengan kemungkinan seseorang untuk berpindah partai.Fenomena pindah partai merupakan bentuk dari ketidakstabilan pemahaman politik seorang calon legislatif.Ini juga menjadi penanda bahwa partai tidak mampu memberikan pendidikan politik yang baik untuk kader partainya. Oleh sebab itu, tingkat kepercayaan dan loyalitas seorang calon legislatif akan berpengaruh pada pendewasaan kader partai dan perkembangan partai itu sendiri.

Dari pembahasan di atas dapat disimpulkan bahwa orientasi kognitif calon legislatif perempuan tergambar melalui seberapa besar minat dalam berpolitik dan seberapa besar tingkat kepercayaan terhadap lembaga politik seperti partai politik dan lembaga pemerintahan.Minat yang ditunjukkan oleh calon legislatif perempuan di kabupaten Ogan Komering Ulu mengarah pada minat yang didorong oleh keingintahuan dan pemahaman mereka tentang politik karena sudah seharusnya minat dalam pengertian orientasi kognitif harus mengarah pada kepentingan dan pengetahuan dalam politik (Ishiyama, 2013).

Dalam hal kepercayaan terhadap lembaga politik, calon legislatif perempuan menjadikan kepercayaan mereka terhadap partai politik sebagai bentuk penerimaan partai yang telah menjadikan mereka kader dan bahkan mengajukan mereka menjadi calon legislatif.Maka hubungan yang berlaku bagi calon legislatif perempuan dan partai adalah hubungan yang saling menguntungkan dan akan menggiring pada hubungan yang sifatnya loyalitas. Kepercayaan ini juga akan membentuk pribadi calon legislatif perempuan untuk mampu maju dan bersaing dengan calon legislatif lainnya.

b. Orientasi Afektif

Orientasi afektif menunjukkan pada perasaan khusus terhadap aspek-aspek sistem politik tertentu yang dapat membuat seseorang menerima atau menolak sistem politik tersebut, peranannya, aktor dan penampilannya.Komponen afektif yang melibatkan perasaan ini dapat dipengaruhi dari lingkungan hidup dimana seseorang tersebut tinggal.

Orientasi afektif digunakan untuk mengetahui bagaimana perasaan pribadi seseorang sebagai suatu anggota sistem politik.Bagaimana pemahaman seseorang tentang hak dan kewajiban serta strateginya untuk dapat memasuki kelompok-kelompok yang berpengaruh.Bagaimana penilaian mereka terhadap kemampuan dalam aturan partisipasi yang mereka gunakan dalam memberikan penilaian politik atau dalam menyampaikan pendapatnya.

Pada konteks ini, sikap dan perasaan yang dimiliki oleh calon legislatif perempuan terhadap sistem politik menjadi fokus orientasi afektif.Perasaan merasa memiliki partai, perasaan ikut berperan dalam setiap kebijakan yang dikeluarkan partai maupun pemerintahan menjadi landasan seseorang dalam mencalonkan diri sebagai calon legislatif.

Sebagaimana yang diungkapkan oleh Indrawati dan Umi Hartati, Perempuan akan cenderung memilih partai dengan mengedepankan perasaan antara suka dan tidak suka terhadap partai. Bagaimana sikap partai terhadap kader perempuan, bagaimana kader perempuan selama ini berkiprah di partai, bagaimana dukungan partai terhadap kebijakan-kebijakan yang menguntungkan perempuan atau mengedepankan isu-isu perempuan. Sikap ini akan menjadi catatan untuk pemilihan partai. Selain sikap tersebut, kecenderungan akan ketokohan partai juga menjadi titik seorang perempuan untuk memilih partai, terlebih lagi partai yang dianggap bersih dan berisi orang-orang yang berintegritas tinggi.

Pada intinya orientasi afektif ditunjukkan melalui pemilihan partai politik dan tingkat pengetahuan mereka sistem politik secara luas.Selain itu, orientasi afektif ditunjukkan dengan keikutsertaan mereka dalam kontestasi politik secara langsung.

c. Orientasi Evaluatif

Orientasi evaluatif merupakan keputusan dan pendapat tentang objek-objek politik yang secara khas melibatkan kombinasi standar nilai dan kriteria dengan informasi dan perasaan yang memang telah dimiliki oleh seseorang.

Orientasi ini menunjukkan pada sikap politik individu yang sudah terlibat aktif dalam proses politik. Dalam orientasi evaluatif, seseorang sudah memahami betul setiap proses politik yang sedang berjalan. Hal ini dicontohkan melalui seserorang yang terlibat aktif dengan kegiatan politik seperti sosialisasi partai politik, kampanye politik dan lain sebagainya.

Seseorang sangat memahami pentingnya dirinya mensosialisasikan suatu partai politik dengan tidak melupakan ketokohan sebagai simbol dari partai itu 
sendiri. Kombinasi antara perasaan individu yang menyadari dirinya bagian dari sebuah proses dan harus memberikan kontribusi bagi keberhasilan proses tersebut serta informasi yang cukup menjadikan orientasi evaluatif benar-benar ditunjukkan melalui sikap kesadaran berpolitik yang sudah matang.Kesadaran politik menjadi ukuran penting dalam orientasi evaluatif ini karena harus ada pembeda antara seseorang yang aktif dalam proses politik. Dikhawatirkan keaktifan seseorang dalam kegiatan politik bukan karena kesadaran, namun adanya intimidasi politik tertentu.

Pada calon legislatif perempuan di Kabupaten Ogan Komering Ulu, orientasi evaluatif ditunjukkan melalui argumentasi mereka tentang pentingnya kuota 30\% keterwakilan perempuan bagi perempuan.Menurut Indrawati adanya kuota ini sebenarnya sangat menguntungkan bagi perempuan. Melalui kebijakan ini perempuan akan lebih mudah untuk ikut berpartisipasi aktif dan mengembangkan potensi diri perempuan dalam politik dengan baik. Hal yang sama juga disampaikan oleh Umi Hartati jika adanya kuota 30\% semakin membuat perempuan mempunyai akses lebih luas untuk mengartikulasikan kepentingannya, selain itu, dengan kebijakan ini maka untuk mewujudkan kebijakan yang mampu mengcover kepentingan perempuan akan semakin mudah diwujudkan.

Dari dua pernyataan tersebut dapat disimpulkan bahwa pengetahuan mereka tentang sistem politik dan bagaimana mengartikulasikan kepentingan mereka dalam konteks kepentingan perempuan sudah mampu memberikan mereka alasan yang kuat untuk mencalonkan diri dan menjadi bagian aktif dari suatu sistem politik.

Dari ketiga orientasi tersebut dapat disimpulkan bahwa budaya politik bagi calon legislatif perempuan di Kabupaten Ogan Komering Ulu adalah budaya politik partisipan.Mereka sudah mampu menyuarakan aspirasi mereka.Mampu memberikan tanggapan pada kebijakan yang dinilai tidak menguntungkan bagi perempuan dan mampu memberikan tanggapan terkait dengan sistem politik.

\section{Motivasi Politik Calon Legislatif Perempuan}

Terkait dengan motivasi politik calon Legislatif perempuan, teori kebutuhan Maslow digunakan untuk memetakan motivasi perempuan dalam mencalonkan diri menjadi anggota legislatif. Secara naluriah, manusia akan selalu memiliki motivasi dalam kehidupannya. Motivasi yang diartikan sebagai kekuatan yang muncul dari dalam ataupun luar diri seseorang yang membangkitkan semangat dan ketekunan untuk mencapai suatu keinginan merupakan proses yang akan terjadi dalam setiap diri manusia dan motivasi secara mendesak akan muncul jika berkaitan dengan kebutuhan. Manusia akan selalu menginginkan kebutuhannya terpenuhi. Pada faktor pemenuhan kebutuhan, manusia akan selalu termotivasi untuk melakukan segala kegiatan oleh sebab itu motivasi dapat dikatakan sebagai faktor pendorong aktivitas dan perilaku manusia.
Pada hirarki teori kebutuhan Maslow disebutkan bahwa kebutuhan manusia dimulai dari kebutuhan dasar hingga kebutuhan untuk berkembang. Adapun kebutuhan dasar manusia dibagi menjadi kebutuhan fisiologi yaitu yang berkaitan dengan makan, minum, kebutuhan vitamin dan yang berkaitan dengan kepuasan secar fisiologi termasuk seks.Kebutuhan dasar yang kedua adalah kebutuhan rasa aman.Manusia seyogyanya selalu menginginkan hal yang baik dan dalam kondisi yang stabil, baik itu terkait dengan keamanan, stabilitas ekonomi, sosial, budaya dan politik dan terutama terbebas dari rasa cemas dan takut. Kemudian kebutuhan dasar yang ketiga adalah kebutuhan akan cinta, rasa memiliki dan perasaan menjadi bagian dalam suatu kelompok di masyarakat. Kebutuhan ini biasanya menjadi penyebab munculnya psikopatologi karena kurangnya rasa dicintai atau dihargai oleh kelompok disekelilingnya.

Selain kebutuhan dasar, manusia juga mempunyai kebutuhan pengembangan atau untuk berkembang.Kebutuhan pengembangan yang pertama adalah kebutuhan untuk dihargai. Dalam konteks ini adalah kebutuhan untuk mendapatkan pengakuan, kebutuhan akan status yang tinggi dalam masyarakat dan mampu mendominasi. Selanjutnya kebutuhan pengembangan lainnya adalah kebutuhan aktualisasi diri.Dalam kebutuhan ini manusia menuntut dirinya untuk dalam mengaktualisasikan potensinya dalam bentuk pembentukan pribadi yang lebih baik.Selain itu, manusia juga mempunyai keinginan untuk lebih kreatif dan responsif.

Berdasarkan pada pengelompokkan teori kebutuhan di atas, motivasi calon legislatif perempuan di Kabupaten Ogan Komering Ulu masuk dalam kategori pemenuhan kebutuhan untuk dihargai.Selama ini perempuan berada dalam status sebagai second sex yang merasa termarginalkan dengan peluang laki-laki di ranah publik.Kaum perempuan menginginkan dirinya mampu mengembangkan kompetensi mereka, kemandirian mereka dan meningkatkan rasa percaya diri mereka sehingga mereka tidak termarginalkan dalam struktur sosial di masyarakat khususnya dalam sistem politik.Perempuan juga menginginkan adanya apresiasi dari masyarakat atas prestasi mereka bukan semata-mata dipandang sebagai kelompok yang minim pengetahuan dengan kepentingan yang tidak terlalu signifikan.Pada konteks ini perempuan menginginkan adanya kesamarataan dalam peluang yang diberikan antara kaum laki-laki dan perempuan dalam ranah publik.

Dari penjelasan di atas, penelitian ini merupakan penelitian yang menitikberatkan pada hubungan kausalitas antara orientasi politik perempuan dengan motivasi politik perempuan dalam pencalonan mereka sebagai anggota legislatif.Dengan adanya kebijakan affirmative action kaum perempuan tentunya mempunyai peluang besar untuk dapat ikut serta dalam partisipasi yang lebih aktif dalam dunia politik.Dukungan kebijakan ini menjadikan perempuan mempunyai posisi tawar dalam politik.Kebijakan 
affirmative action juga membuka peluang bagi partai untuk lebih memperhatikan posisi perempuan di partai.

Tidak dapat dipungkiri jika kebijakan affirmative action sebenarnya memiliki sisi yang dapat menguntungkan namun juga merugikan.Peluang dengan adanya kebijakan ini banyak tidak termanfaatkan karena pada faktanya banyak perempuan tidak memiliki keinginan untuk berpartai dan ikut dalam kontentasi politik.Hal ini tidak terlepas dari dukungan sosial dari perempuan berupa dukungan sosial, ekonomi dan budaya. Kebanyakan perempuan akan berpikir panjang jika menyangkut izin keluarga dan kondisi perekonomian keluarga dan budaya yang melingkupinya selama ini. Oleh sebab itu, partai juga mengalami kesulitan dalam perekrutan dan pengkaderan anggota partai karena sebagian besar terkendala dengan faktor tersebut.

Berdasarkan pada fakta di atas, prospek partisipasi perempuan dalam pemilu-pemilu yang akan datang menjadi tidak terprediksi karena dalam politik sendiri tidak ada yang pasti. Keinginan masyarakat kadang berubah sesuai dengan kondisi mereka.Hal ini menjadikan dunia politik mempunyai dinamika yang sangat statis dan cenderung tidak stabil.Oleh sebab itu, prediksi saat ini tidak dapat dijadikan rujukan untuk melihat prospek kedepan.Adapun yang perlu digarisbawahi dalam hal ini adalah partai yang dituntut untuk lebih matang dalam kelembagaannya sehingga mampu merekrut dan mengkader perempuan-perempuan potensial agar mampu menjadi agen perubahan.

\section{Kesimpulan}

Partisipasi politik perempuan secara umum dipengaruhi oleh kurangnya sosialisasi dan pendidikan politik dari partai politik dan dukungan sosial masyarakat. Hal ini berpengaruh pada motivasi perempuan yang tidak ikut serta dalam kontestasi politik. Sementara motivasi perempuan yang menjadi calon legislatif dipengaruhi oleh keinginan untuk mengembangkan potensi diri perempuan dalam lingkup yang lebih luas

\section{Daftar Pustaka}

Almond, Gabriel A dan Sidney Verba. 1984. Budaya Politik; Tingkah Laku Politik dan Demokrasi di Lima Negara: Bina Aksara. Jakarta

Alwisol, 2009.Psikologi Kepribadian Edisi Revisi (Original). UMM Press. Malang.

Arikunto. Suharsimi.2010. Prosedur Penelitian; Suatu Pendekatan Praktik: Rineka Cipta.Jakarta

Bungin, Burhan. 2010, Metodologi Penelitian Kualitatif : Komunikasi, Ekonomi, dan Kebijakan Publik serta Ilmu-ilmu Sosial Lainnya: Prenada Media Group. Jakarta

Halim, Abd. 2014. Politik Lokal; Pola, Aktor, dan Alur Dramatikanaya. LP2B. Yogyakarta

Ishiyama, John T dan Mrijke Breuniing. 2013. Ilmu Politik Dalam Paradigma Abad ke Dua Puluh Satu.
Penerjemah Ahmad Fedyani Saifuddin: Kencana. Jakarta

Moleong, Lexy J. 2012. Metodologi Penelitian Kualitatif: Remaja Rosdakarya. Bandung

Mujani, Saiful. 2007. Muslim Demokrat; Islam, Budaya Demokrasi, dan Partisipasi Politik diIndonesia Pasca Orde Baru: Gramedia Pustaka Utama. Jakarta

Sahid, Komarudin. 2011. Memahami Sosiologi Politik: Ghalia Indonesia. Bogor

Sorensen, George. 2014. Demokrasi dan Demokratisasi.Pustaka Pelajar. Yogyakarta

Wahid, Umaimah. 2014. Risalah Politik Perempuan: Media Massa dan Gerakan CounterHegemony: Empat Pena Publishing. Tanggerang. 